\title{
Javanese Politeness: Strategy Of Politeness Of Fta Recipients In Kbj Vi
}

\author{
Suyami $^{1}$, Djatmika ${ }^{2}$, Sumarlam $^{3}$, Dwi Purnanto ${ }^{4}$ \\ \{suyamibpsnt.jogja@gmail.com ${ }^{1}$, djamika@ staff.uns.ac.id ${ }^{2}$, sumarlamwd@gmail.com ${ }^{3}$, \\ dwi.purnanto@yahoo.com ${ }^{4}$ \} \\ 1,2,3,4 Sebelas Maret University, Solo, Indonesia
}

\begin{abstract}
This paper discusses face threatening act strategies in responding to 'face threatening speech acts' that afflict hearer. This article is extracted from the results of research on the speech acts of the participants of the Kongres Budaya Jawa (KBJ) VI or Javanese Culture Congress. It is known, in the speech act of the involved KBJ VI, there were suspected threatening face speech acts (FTA), which were carried out by several actors, namely presenters, moderators, and responders (audiences). FTA is a speech that is less solid because it can make the speech partner feel embarrassed and feel unhappy, so that it has the potential to provoke an angry reaction for the recipient. This research departs from the problem, This study aims to uncover the reaction of FTA recipients to threatening facial actions that embarrass themselves and presenting an overview of politeness strategies applied by FTA recipients in responding to FTA perpetrators regarding themselves. The research method is done by recording, recording, sorting, selecting. Data collection was carried out by recording and recording all acts of speech involving the involvement of the VI KBJ, especially official conversations in the trial. The recordings and notes are then sorted between conversations containing FTAs and those that are not, then a speech act which has the potential to contain FTAs is chosen, then the FTA recipient's reaction in response to the FTA is assessed which threatens his face. The results of the study showed that there were several kinds of reactions from FTA recipients in dealing with and responding to FTAs that caused their faces. Some of them responded by laughing and jokingly acknowledging their mistakes, there were those who were silent without a reaction as if ignoring it, some responded with a smile without words, some responded with more self-humiliation. These various reactions are more of a politeness strategy from FTA recipients in maintaining harmony and peace so that no significant tension occurs. It is like the Javanese politeness teaching " amemangun karyenak tyasing sesama " (trying to make others happy). The overview of politeness strategy is also shown as the result of the problem as the positive respond to face threatening act.
\end{abstract}

Keywords: face threatening act; threatening face speech acts; politeness strategy

\section{Introduction}

KBJ (Javanese Language Congress) VI is a meeting place for Javanese Language practitioners and Javanese lovers, who discuss the ins and outs of Javanese language in the present to the possibility of its sustainability in the future. KBJ VI is an event for stakeholders related to the existence of Javanese language conducted by selected people who are competent in the Javanese culture, especially in the field of Javanese. Javanese is one of the many regional languages in Indonesia. Javanese is called, because the language is generally used by ethnic Javanese. Javanese politeness is a code of manners and morality that applies in Javanese ethnic life. A Javanese king, KGPAA Mangkunegara IV (1809-1881) expressed the need to emulate the main deed of the founder of the Mataram Kingdom, namely Panembahan Senapati, which day and night always builds amemangun karyenak tyasing sesama (trying to 
make one's heart good) (Mangkunegara IV, 1921: 5). This expression is the essence of Javanese politeness, where all the teachings of politeness always boil down to make other people happy. The teachings of politeness in Javanese culture are manifested in several wise expressions, such as: tepa slira (tolerance), lembah manah (humble), andhap asor (humble oneself), and ngajeni (respect).

FTA (face threatening act) is "face threatening action". 'Face', according to Brown and Levinson (1988: 61), which raises from Goffman's idea (1967), from English folk terms, is something related to the idea of the existence of shame or humiliation, or 'losing face'. If it is associated with Javanese politeness teachings, developing the interests of others (trying to make others feel good), FTA acts are not polite, which results in causing shame and making bad feelings for partners.

Brown \& Levinson define 'face' as the public self-image that everyone wants. In that case Brown and Levinson distinguish faces in two aspects, namely 'face negative' and 'face positive'. Negative faces are basic claims to the region, personal preserves, rights to noninterference, namely freedom of action and freedom from imposition. A positive face is a consistently positive self-image or 'personality', (especially including the desire that this selfimage be valued and approved) claimed by interactants.

That way it can be interpreted that 'face' is a self-image as well as a mirror of selfesteem. According to Brown and Lavinson, face is something real, invested emotionally, and it can be lost, can be maintained, or improved, and must always be considered in interactions (Brown \& Levinson, 1988: 61). As Brown and Levinson's expression of 'face', which is associated with shame or humiliation, or 'loss of face', it is also in line with the context of 'shame' in Javanese culture, which is called the term 'rai' (face). In Javanese culture, people who are in a state of shame are called ora duwe rai (no face). The person who does not have shame is referred to as 'rai gedheg' (face 'woven bamboo') or rai tembok (face wall). That is, the person is likened to an inanimate object that has no feelings. Someone who is in that condition and position, surely his heart feels bad.

In the principle of politeness, things are considered as "face threatening act" (FTA), including "speech acts", namely speech acts that can have the effect of causing shame to the partner's speech. In Javanese culture, the level of politeness of speech acts will appear in the application of language uploads, according to the level order of the gradations of Javanese grammar. Javanese has a gradation in the level of politeness that is realized in the form of a gradation level (undha usuk unggah ungguh) language, which initially consisted of 7 levels, namely ngoko, madya, krama, krama inggil, basa kedhaton, krama desa, and basa kasar (Ministry, Teaching, Education and Heritage, 1947: 64). In the subsequent development, the level gradation of simplified Javanese speech level only became two classes, namely Javanese ngoko and krama. Javanese Ngoko is divided into ngoko and ngoko alus. Javanese language is divided into Krama and alus (Harjawiyana, 2005).

Javanese is not only a communication tool, but also able to describe the situation of the level of intimacy and politeness of the actors said. The use of the two types of Javanese, ngoko and krama, serves as benchmarks for the level of mastery of courtesy for the speakers. KBJ VI is intended to preserve the Javanese language along with the noble values contained in it. However, in the KBJ VI event, there were allegedly acts or irreverent remarks by some involvement in these activities, which results in creating FTAs for recipients. In this regard, this study raises the issue, 1) how the FTA recipients react to the threatening actions of the face that embarrass themselves; 2) What is the politeness strategy applied by FTA recipients in responding to FTA to them. 
This study aims to: 1) uncover the reaction of FTA recipients to threatening facial actions that embarrass themselves; 2) Presenting an overview of politeness strategies applied by FTA recipients in responding to FTA perpetrators regarding themselves.

According to the Kamus Besar Bahasa Indonesia (1995: 878), the word 'politeness' comes from the word 'polite' which means, among others: 1) Fine and good (mind the language, behavior); polite, patient and calm; 2) Full of compassion; helpful. In this case the word 'politeness' can be interpreted al regarding the subtlety and kindness of language and behavior; about courtesy, patience and calm; about compassion and helpfulness. Modesty is the main device in the behavior of human life in order to maintain harmony and peace. Not a few events because of the act of violating politeness ended fatally, ended at the court table, and even ended in death. For example, the case of George Yunus Aditjondro, the case of Florence Saulina Sihombing, and the case of the murder of Nanda Amalia Setyowati, a junior high school student in Depok, Sleman, only because of statements that were deemed unpleasant to others.

The purpose of politeness is to maintain harmonious social relations (Cruse, 2000: 362; in Gunarwan, 2007: 164). Cruse said that for the sake of politeness, in speaking we need to choose the phrase that is least likely to cause the speech partner to lose face. In the principle of politeness, speaking is not of sound origin, but it is necessary to choose a strategy, especially in maintaining the face of the partner, avoiding words that can threaten the face, or humiliating the partner so that the partner feels loss of face (Brown and Levinson 1987: 61; Yan Huang, 2007: 116). Asim Gunarwan (2007: 164), states that the purpose of politeness is to maintain harmonious social relations. As with Brown and Levinon's politeness principles, namely the principle of maintaining the face of a speech partner. In discussing 'politeness' there are four models that can be guided, namely: a) the model of 'social norms' (Watts 2003), b) the model of 'maxim conversation' (Leech 1983, 2003), c) the model 'face saving' '(cover shame) (Brown and Levinson 1978, 1987), and d)' conversational contract 'models (Fraser 1990).

The study entitled "Javanese politeness: The strategy of politeness of FTA recipients in KBJ VI" will refer to Brown and Levinson's politeness theory of "face-saving" (closing shame). The essence of Brown and Levinson's theory of politeness lies in Goffman's sociological proposition of face (face), which is simply interpreted as' the general self-image that each member will demand for himself '(Brown and Levinson 1987: 61), or' appreciation individual self '. In this case there are two aspects to the face, namely 'face positive' and 'face negative'. 'Positive face '(positive face) is something that describes an individual's desire to be accepted and liked by others. The orientation of courtesy to maintain the positive face of others appears when someone tends to choose a speech strategy that emphasizes solidarity with the speech partner, conveying that the speaker and the partner are in the co-operator, and the speaker tries to satisfy the wishes of the partner (Brown and Levinson 1987: 101-29).

Negative face refers to the right of an individual to free his actions and actions not to be determined by others. Negative politeness is oriented towards negative face maintenance in the speech partners when someone tends to choose a speech strategy that emphasizes the selfdefense of said partner. Actions that can threaten a positive face include expressions of reproach, accusation, criticism, disapproval, and insults. Actions that can threaten negative faces include advice, orders, requests, suggestions, and warnings. Actions that can threaten positive faces and negative faces include complaints, interruptions, and threats.

Speakers can threaten their own faces if they take action to receive praise, express gratitude, and make a confession. While actions that threaten the face of a partner are actions such as advising, reminding, and expressing strong emotions that really threaten the face of the desired partner (Brown and Levinson 1987: 67-8). Writing about Javanese politeness has 
been carried out by Asim Gunarwan with the title "The Feeling of Jealousy and Disclosure of Speech Acts of Face Threaters among Javanese" (Gunarwan, 2008; in Katharina E.S. (Editor), 2008: 427-458). However, the article specifically discusses various politeness strategies in speech acts prohibiting, for example, prohibiting smoking, among Javanese people.

Sumarlam (1994) also discussed "Pragmatic Scale and Degree of Courtesy of Directive Speech". However, the paper only discusses the degree of Javanese politeness in directive speech acts. Anat Zajdman (1994) discusses humorous FTAs and the strategic advantages of humor. In this article Zajdman peels out the funny FTA with the topic 'Humor as a strategy'. Zajdman follows the opinion of Brown and Levinson (1978) who assume that joking is one of politeness techniques, namely as a strategy used to minimize threats to one's positive face. Awareness of positive politeness is a way to minimize social distance. Joking can serve a purpose to make the listener feel comfortable. Joking can also be intended to evoke feelings of intimacy and friendship (Zajdman, 1995: 327). Zajdman gave an example, funny FTA is usually done in the world of clowns. Where, the clown will save his face when he is laughed at. For clowns, not being laughed at means disgrace (Zajdman, A., 1995: 332).

Bavelas, J. et al. (2017) discuss the need for mutual understanding: calibrating the micro sequence in face-to-face dialogue (Doing mutual understanding. Calibrating with microsequences in face-to-face dialogue). Gil, J.M. (2012) interpreted the phenomenon of politeness by examining face-threatening speech acts and face-attacking speech acts (Face-Threatening Speech Acts and Face-Invading Speech Acts: An Interpretation of Politeness Phenomena). Gil states that all speech acts, all utterances, are inevitable inevitably affecting the face of the speaker and listener. This thesis brings us to the difference between rude and rude speech acts. Irreverent speech acts will threaten the face of the speaker and listener. The rude speech acts will attack the listener's face and result in the speaker's face. For this reason, it is suggested that acting in speech must pay attention to three principles, namely 1) love for the face; 2) avoid irreverent speech acts, which can threaten the face; 3 ) avoid rude speech acts that can attack the face.

Kienpointner, M. (1997) examines the variety of rudeness, types and functions of impolite speech (Varieties of rudeness, Types and functions of impolite utterances). Regarding this, Kienpointner contrasts politeness and rudeness. Modesty is a kind of cooperative communication, a prototype of behavior that stabilizes the personal relationships of individuals who interact, making it easier to achieve the goals received together in interacting. Modesty creates or maintains an emotional atmosphere of mutual respect and sympathy, for the benefit of both (all) people involved. Modesty aims to avoid actions that threaten the face and choose or emphasize actions to improve the face. In this sense, politeness is closely related to mutual cooperation and can be characterized as a combination of routines and strategies used to increase cooperative interaction by 'building and balancing personal relationships between individuals during the interaction process.

Roughness is a prototype of non-cooperative or competitive communication behavior, which shakes the personal relationships of individuals who interact so that it makes it more difficult to achieve goals that are accepted together from interactions or make it difficult to agree to the goals that are accepted together in the first place. Rudeness creates or maintains an emotional atmosphere of mutual disrespect and antipathy, and serves egocentric interests. In this case 'rudeness' is used as a closing term for all types of verbal behavior that are not polite, and emphasizes actions that threaten the face and hold or weaken facial enhancement actions.

In fact, there have been quite a number of writings that have discussed the disadvantages of face threatening speech acts and their effects, both for the speech partners and for the 
speakers, such as Maria Sifianou (2012) about Disagreement, face and courtesy (Disagreements, face and politeness). Sifianou is based on Sacks (1973/87); Promerantz (1984) who thinks that 'disagreement' will greatly damage social solidarity, but then compared with the opinion of Schriffrin (1984) which reverses that debate or opposition between friends can signal sociability rather than violation of modesty. The results of Sifianou's research show that the disagreement does not need to be seen only in negative terms. It does not necessarily produce conflict and immodesty, but it can be a sign of intimacy and socialization and may not be destructive but rather strengthen relationships with the other person unlike the opinion of Myers 2004: 112), who observed that disagreement had acquired a bad name, it was considered as a kind of failure between interactants. In line with Myers, Pomerantz, who considered that disputes were disliked because they disagreed with each other, made them uncomfortable, unpleasant, difficult, risking threats, insults or violations, while agreeing with each other was comfortable, supportive, strengthening, and possibly sociable, because this shows that the interlocutor thinks the same.

This study seeks to uncover and present strategies for politeness of speech acts of recipients of FTAs in the activities of the KBJ VI, in response to the FTA they received. As far as the researchers know, so far no research has been found on the strategy of politeness of FTA recipients, especially those that occur in the activities of the KBJ VI.

\section{Method}

This research is a type of qualitative research. The data studied is in the form of words. The technique of data collection is done through observation and collection of documents in the form of speech act cases that can potentially threaten the face of the partner, as well as the reactions and politeness strategies carried out by FTA recipients in response to FTAs that embarrass him. Research is carried out in natural settings because the reality studied is wholeness that cannot be adequately understood if it is detached from the context. The natural setting is also a context for the meaning of the research findings. The natural setting in question is the setting as it is, which is not manipulated or engineered by researchers, which in this case is the conversation situation of the KBJ VI broadcasters during the trial.

The selection of research samples using purposive sampling. The researcher selects the data source based on certain criteria relevant to the research topic, as long as the data source is able to provide the necessary information. In this case, the number of samples is not important. The data needed in this study are oral data, namely data obtained through speech, in the form of speech acts carried out by the participants of the KBJ VI, which took place in Yogyakarta on 8-12 November 2016, especially regarding the reactions and politeness strategies applied by the FTA recipients of the FTA they received. Data sources are obtained from formal speeches or official conversations that take place during the implementation of KBJ VI activities, which occur in court activities, both MC speech acts, Moderators, Speakers / resource persons, and questioners / responders.

The methods and techniques for providing data are done by recording, see, note. The first step is to record all the official conversations of the participants of the KBJ VI, both the MC's remarks, moderators, speakers / resource persons, and questioners and responders. The recordings are then listened to and recorded by transcription. Furthermore, from the results of the transcript, the recording and collection of data in the form of reactions and the politeness of the FTA recipients towards the FTA were received. 
The method and technique of data classification is done by sorting and selecting all speech acts which are the reactions and strategies of FTA recipients to FTAs that embarrass themselves. From all of the data, then selected several samples of data which will then be analyzed in order to obtain conclusions from the research results. Data validation methods and techniques are carried out by returning the data in its context. The data is checked again in order to get the identity of the speaker and the partner, and pay attention to the context of the conversation. Does the speech/act appear in the context of joking or in serious conversation.

The method and data analysis is done by paying attention to the speech actions of the FTA recipients in response to the FTA they receive and paying attention to the context of the conversation. This was done to find out the reactions and politeness strategies of FTA recipients to the FTA they received. The reaction of FTA recipients here can be in the form of speech / reply speech acts or answers or in the form of an attitude or body language. That reaction is used as the basis for making conclusions.

\section{Result and Discussion}

In the study it was found that there were 5 contexts of conversations containing FTAs, both those carried out by moderators, resource persons, and audiences, which directly and indirectly had the effect of causing shame to the recipients. The four contexts in this article are marked with code $\mathrm{K} 1$ for context I, then for speakers will be coded P1, and for the partner will be coded M1. In context II it will be marked with a $\mathrm{K} 2$ code, then for speakers will be given a P2 code and for the speech partner coded M2. In context III it will be marked with a K3 code, then for speakers given the code P3 and the partner of speaking given the M3 code. In context IV it is marked with code $\mathrm{K} 4$, for speakers given code $\mathrm{P} 4$, for speech partners coded M4. In context V is marked with code K5, for speakers coded P5, for speech partners coded M5.

Context I:

The event of face threatening speech acts in K1 occurs at a plenary session, between moderators as P1 and resource persons as M1. In this event, the speaker said that the number 1928 (one thousand nine hundred twenty eight) in Javanese with the mention "setunggal ewu sangangatus kalihdasa wolu". The correct mention is "setunggal ewu sangangatus wolulikur". Apparently, the speaker did not realize that what was said was wrong. The speaker continued to talk about the position of Javanese as a regional language in order to strengthen and support the unity language, namely the Indonesian language proclaimed in the event of a youth oath.

In the event, at the end of the presentation P1 joked with a reminder of the mention of the year of the event of the youth oath, which was said by the speaker.

P1: Yes ... let's give applause together as a tribute to the speaker. as the speaker had said earlier, the existence of Javanese as a regional language was inseparable from the slogan of the youth, known as the "Youth Oath", which took place in 'setunggalewu sangangatus kalihdasa wolu' (1928) ... correct ... 'Even though it's bad' ... [should be wolulikur] ... right, ma'am. Minutes ... do not forget to note ... the words of Ibu Sri Hartini ... the oath of the youth of the year as single as it is very difficult ... hahahaha.

M1: yes ...

Audience laughs ......

P1: Yes, brothers and sisters ... year after year you have a very bad feeling.

Audience: ... "wolulikur" ... 
M1: Oops ... wrong huhaha ... sorry ... I am also a Javanese ... yes villagers ... but I have left the village for a long time ... wow ... ... yes there are many who forget ... yes yes ... wolulikur ... how come it feels bad ... hahaha ... excuse me ... sorry ... year setunggalewu sangangatus wolulikur ...... hahaha ... I'm sorry ...

P1: hahaha .... no why ma'am ... if you only mistakenly say wolulikur to be kalihdasawolu ... it will not be punished. Except for the other ... hahaha ...

M1 and audience ... hahaha ...

Context II:

Events of speech acts threatening faces in $\mathrm{K} 2$, occur in a plenary session, between speakers as P2 and committee / audience as M2. The speaker at the session was a level II regional head official. When presenting the material, the resource person commented on the theme of KBJ VI namely "Javanese Tri-Boarding Base". Meanwhile, the material section committee that created the KBJ VI theme was on duty as a moderator in the session.

P2: Javanese language ... smooth, bro ... your heart ... what theme ... tiwikrama? .... who chose that title ... where's the brain you know ... he thinks ... who said what 'tiwikrama' is. Tiwikramanya is in quotes, ... incarnate men incarnate women ... The small ones can become big ... big can be small ... those belong to men ... big all ... Tell him the professor ... expert ... nothing is made difficult ... this is hard ... He said Krishna ... stupid-stupid .... stupid people ... dirty people .... the feeling is small ... but Kresna continues to become big ... strange you know ... To get the book of the Bible .... Kresna tiwikrama ... but the tiwikrama becomes a beetle ... becomes a bee ... so ... ... big to be small. This is where Javanese is spoken ... Javanese ... Which Java ... therefore ... before I speak much ... I can explain this ... indeed 'tiwikrama' can still be maintained ... this seems to have been. The origin is the name of the chemical element water $\mathrm{H} 2 \mathrm{O}$ (hydrocidioxide), which means ... how to replace it ... the important thing is that it still contains $\mathrm{H} 2 \mathrm{O}$ elements ... even though it doesn't have to be one bucket ... I can take one dipper ... Taking a kettle can ... take one glass, can you ... because of the 'tiwikrama' ....

M2: (Committee / moderator \& audience smile)

Context III:

Events of speech acts threatening faces in K3, occur in a plenary session, between speakers as P3 and audience (a young woman) as M3. Same as the speech event on K2, the speaker is still the same, is a level II regional head official. During the trial, the speaker occasionally inserted questions to the audience with prizes. Whoever answers the question of the interviewee gets Rp. 200,000, by providing a prize of Rp. 1,000,000, for five questions. During the presentation of the material, the new resource person managed to issue prizes provided for 2 people, each of which was Rp. 200,000. In the question and answer session, when the trial time was almost up, Rp 600,000 in prize money was left, - the speaker then called the name of an audience.

P3: "... This is six thousand for what is this ... Surti .... Industry .... this is for you Tri ... here Tri ... this ... ... for your child ... to buy milk ... because I need your milk Tri ... this is to buy milk ... not Surti ... how about it ... I am more amazed by you ... more handsome ... you are also more beautiful ... but ... there is no way we will unite ... because of us both. "

M3: (A beautiful woman advances closer to the speaker to receive the money while smiling sheepishly) ...

Context IV:

Events of speech acts threatening faces in $\mathrm{K} 4$, occur in a plenary session, between moderators as P4 and resource persons as M4. The speakers at the session were academics, lecturers at a state university in Surabaya. In exposing the material, the speakers used Javanese 
in various types of ngoko. In his presentation, the speaker stated that in today's society, the Javanese language used in the Surabaya area is a variety of ngoko Javanese. If people speaking in Javanese manners is considered ketoprakan or even in the old age. Therefore, the Javanese language that needs to be preserved is Javanese language. Javanese is a variety of manners that does not need to be preserved because it is unpopular and is not used in people's lives, especially in the Surabaya area. In the session two speakers were presented, namely Ms. Sri Wiryanti from Surabaya who presented her material with Jovanese ngoko, and Ms. Sri Ratna Sakti Mulya from UGM and Nimas Tumenggung Sestradi from Pura Pakualaman Yogyakarta who delivered the material in Javanese etiquette.

P4: Yes ... Mother ... we are like in Suriname ... Yes, that is Ibu Sri Wiryanti Surinamenan ...

Context V:

M4: (the speaker laughs wide ....)

Events of speech acts threatening faces in K5, occur at the plenary session, between audience responders as P5 and resource persons as M5. In this case the respondent audience consists of 5 people, so that in this case it is marked with code P5.1; P5.2; P5.3; P5.4; and P5.5. Similar to the speech event on K4, the resource person was the same as the K4 case, namely Mrs. Sri Wiryanti. Who explained her material in various Javanese languages and stated that in today's society, the Javanese language used in the Surabaya area is a variety of Javanese. ngoko If people speak Javanese, manners are considered ketoprakan or even in the past. Therefore, the Javanese language that needs to be preserved is Javanese language. Javanese is a variety of manners that does not need to be preserved because it is unpopular and is not used in people's lives, especially in the Surabaya area. In the session two speakers were presented, namely Ms. Sri Wiryanti from Surabaya who presented her material with Joko ngoko, and Ms. Sri Ratna Sakti Mulya from UGM aka Nimas Tumenggung Sestradi from Pura Pakualaman Yogyakarta who delivered her material in Javanese etiquette

P5.1: "Question for Mrs. Wir. My question is from Mrs. Wiryanti's statement ... Javanese does not need krama-kramaan [fine language] ... I am not suitable .... Javanese language krama [subtle] is considered ancient ... I also disagree. The existence of this congress ... to restore Javanese to be sustainable like the rules. The Javanese congress was also included ... the discussion ... now the expert is like that. For Java, it should feel different. So yes Mrs. Wir ... once again ... I don't really agree with your opinion ".

P5.2: You see ... coastal language ... whatever ... if the name is Javanese etiquette ... it's still ... there must be. Upload ... manners ... manners ... must exist. In the workshop like this .... show how its efforts in developing ... manners ... upload Javanese language. excuse me the committee .... I don't mean ... it doesn't mean ... it's not suitable ... or disputes Mrs. Sri ... it's like if in wayang ... Nyi Tumenggung [Sakti] is the same as Sembadra [ Arjuna's wife ... .... Sri Surabaya's mother is like Sarpakenaka [Dasamuka's sister daughter], Javanese culture ... Javanese words ... there are still standards. This is in the Javanese congressional event ... this is really a shame ... this ... if Javanese is a childstarch model .... spend a lot of money ... if you only accept it for ridicule [not qualified] ... very unfortunate ... Actually ... sorry ... who is in front of ... these speakers ... if my opinion ... apologize ... not so important. What really matters is ... discussion. So the most important ... provides ... there must be ... there must be a filter ... what is it ... filter ... filtering ... yes filtering ... it must be there ... which is appropriate ... that is appropriate .... what the speaker is. Sorry ... because it's already running ... yeah ... later if there's more ... don't be like this. Excuse me ... it does not mean I insult you ... no ... I share a sense of responsibility for the preservation of the Javanese language. What I mean ... 
empan papan[adjusts the place] ... like that must be really done. What is the cause ... the hand ... the Pati model ... the hands ... the fruit of the hand coming home from this congress should not be disappointed. Don't get to ... from this congress ... his hand ... disappointed in the heart ... don't get it. So ... the point is ... mothers in the front ... actually ... Javanese is everywhere ... the important thing ... adjusts the place ".

P5.3: "Excuse me ... regarding Mrs. Sri's proposal from Surabaya ... I don't really agree ... because ... this proposal ... sorry ... upload it (politeness) is lacking ... indeed ... the brother from Pati is right .... recommends that the Javanese language has rules. Please allow me to speak ... because ... that courtesy and manners ... are actually politeness ... because that language also includes politeness. The words and actions become one ... can be distinguished ... but cannot be separated. So ... sorry ... so there is courtesy and manners ... it can be d discriminating ... but cannot be separated. "

P5.4: about speaking Javanese, just using mangoes ... but about the words of Krama ... we are still using it ... if we cannot use the words of Krama ... later we cannot distinguish between Ibu Kaliyan. ... you guys ... nuwun sewu ... wedus. Iki wedus, what are you doing ... manganese. This is sir .... why are you ... eating. Thus, sir .... same with.... Wedhus. (About speaking Javanese, please, please. But ... about the words of Krama ... we are still using it. If we cannot use the words of Krama ... later we cannot distinguish between father and mother with ... excuse me. ... a goat. "This is a goat ... what is the goat doing ... eating. This is the father ... what are you doing ... eating. So ... father ... same ... goat.)

P5.5: "Mrs. Sri Wiryani ... I use the language of [soft Javanese] manners ... I can accept it, ma'am. [Mrs. Wiryanti: "if you can listen ... if you can't speak] ... yes ... if you can't ... I just use ngoko [plain Javanese language]. The first ... had already been said in Javanese ... krama ... it was rarely used in the Surabaya area. Well ... that .... Mrs. Sri Wiryani ... has an opinion or not ... the Javanese language of manners will disappear from the Surabaya area ... that's when ... The second, the language. ... me and all of you ... also often hear that the Surabaya language is 'awesome'. That's what Javanese language courtesy is ... it's not taught in schools in East Java, especially in Surabaya. "

M5: "I already feel ... like the earth with the sky ... if it's with Bu Sakti ... it's all smooth. The magic of Javanese is smooth. I also agree that the truth is ... the speaker ... if in that congress ... the Javanese language is appropriate. I sent articles in Indonesian. I already felt that I could not speak fine Javanese. It's usually just short ... but if you arrive like Mrs. Sakti ... you can't. I usually shop. So I'm sorry, Mother ... if I use Javanese ... because if it's smooth, it can't run smoothly. I also agree with you ... if Javanese is true ... it must be preserved. But how else ... if in the community left and right like me ... does not support the use of subtle Javanese. I live in East Java ... especially in Surabaya. If there are Javanese-speaking students like real Javanese ... like Javanese in Yogyakarta ... Solo ... that is said ... "why is ketoprakan". That is indeed a fact. And I revealed ... my article was based on facts. I don't ... don't engineer. Yes ... I also admit ... the rules of manners ... tata sila ... have you not ... yes ... already using Indonesian. Mr. flush shit [you have showered] .... you can. And sometimes my servants say ... kula sampun dhahar $[\mathrm{I}$ have eaten $=$ fine Javanese $]$... mother until ... mangan $[$ mother has eaten = Javanese ngoko language] ... that is indeed the reality in Surabaya. So sorry ... if $\mathrm{Bu}$ Sakti ... in the Pakualaman region ... which was forged by fine Javanese. And I am also very suggesting ... if the speaker should be like Ibu Sakti ... because this is indeed the Javanese congress which preserves Javanese. So actually I am sitting here ... it is also not my will ... I ... what I am saying is the language that is now there ... Yes indeed if 
Javanese is still alive ... in the Surabaya area ... Yes ... that's what you have to ... I want to ... I ... I still love Javanese ... but the Javanese language for uploading is not clearly accepted ... moral conduct. ... manners ... including Javanese language and noble Javanese behavior ... it can indeed be sorted ... but cannot be separated. I am very happy Javanese ... I have Javanese blood. but because I lived a long time in Surabaya ... I have forgotten, let alone I teach students from various ethnic groups ".

\section{Discussion}

As stated earlier, this study refers to Brown and Levinson's politeness theory of 'facesaving', which is based on Goffman's sociological proposition of face, which is simply interpreted as 'self-image'. In general, every member of the community will demand appreciation for him in two aspects of the face, 'face positive' and 'face negative'. Actions that can threaten a positive face include expressions of reproach, accusation, criticism, disapproval, and insults. Actions that can threaten negative faces include advice, orders, requests, suggestions, and warnings. Actions that can threaten positive faces and negative faces include complaints, interruptions, and threats.

'Positive face '(positive face) is something that describes an individual's desire to be accepted and liked by others. The orientation of courtesy to maintain the positive faces of others appears when someone tends to choose a speech strategy that emphasizes race a solidarity with the speech partner, conveying that the speaker and the speech partner are in the co-operator, and the speaker tries to satisfy the wishes of the partner (Brown and Levinson 1987: 101-29).

Negative face refers to the right of an individual to free his actions and actions not to be determined by others. Negligence modesty is oriented towards negative face maintenance in the speech partners when someone tends to have a speech strategy that emphasizes the selfdefense of the partner's speech. In five cases this study was suspected of threatening the face of FTA) carried out by speakers (P), which was then reacted by the speech partners $(\mathrm{M})$. The FTA action taken by P1, included in the positive face FTA category, is in the form of an expression of criticism of said mistakes made by M1. In response to that, M1 reacted with a laugh and acknowledged his mistake with a positive face. Thus, the action of M1 in response to FTA from P1 chose a politeness strategy by maintaining a positive face P1.

FTA actions carried out by P2, included in the positive face FTA category, are in the form of expressions of reproach towards the creators of the KBJ VI or M2 theme ideas. In response to that, M2 reacted by smiling wordlessly on a positive face. Here M2's actions in response to FTA from P2 chose politeness strategies by maintaining a positive face P2. The FTA action carried out by P3 belongs to the negative face FTA category, which is in the form of an order delivered by P3 to be carried out by the M3. In response to that M3 reacts by smiling wordlessly by carrying out the action ordered P3. Here the M3 action in response to FTA from P3 chose politeness strategies by maintaining a positive face P3. The FTA actions carried out by P4, included in the positive face FTA category, namely in the form of comments or subtle criticisms of the various languages used by M4, namely Javanese ngoko style as used by Javanese people living in Suriname. In response to that, M4 reacts with a smile without words. That way, it means that the action of M4 in response to FTA from P4 chooses politeness strategies to maintain a positive face $\mathrm{P} 4$. 
The FTA action performed by P5 (P5.1, P5.2, P5.3, P5.4, P5.5) belongs to the category of positive face FTA and negative face. Positive face FTA was carried out by P5.1 and P5.3, where both of them frankly stated they did not agree with the opinion of M5. Negative face FTA is carried out by P5.2, P5.3, P5.4, and P5.5. P5.2 observes and advises M5 to review his statement which states that Javanese language that needs to be preserved is Javanese with various types of ngoko. According to P5.2, P5.3, P5.4, Javanese, in addition to being a communication tool, is also a means of education in manners, trapsila (courtesy courtesy), which is manifested in the stratification of various Javanese languages manifested in a variety of Javanese languages. ngoko and krama. If the Javanese language of various manners is eliminated, the value of courtesy of Javanese language compensation will also be lost. Therefore, the use of the Javanese language must be empan papan, according to the situation and needs because basically in the Javanese language system, between words lan patrap (speech and behavior), can be distinguished but cannot be separated.

In responding to that, M5 reacted with a strong objection, that what was delivered was not the result of his design, but the fact that was in the field. This means that the M5 action in response to FTA from P5 chooses politeness strategies to maintain a negative face. It appears that he takes a defensive attitude in an attitude that others do not want to determine. however, on the other hand M5 also agreed in part to the opinion of P5, but he could not do it.

This study is different from the earlier study about face threatening speech acts and their effects. Maria Sifianou (2012) talks about Disagreement, face and courtesy (Disagreements, face and politeness). Sifianou's opinion is based on Sacks (1973/87). The following study is conducted by Promerantz (1984) who thinks that 'disagreement' will greatly damage social solidarity, but then compared with the opinion of Schriffrin (1984) which reverses that debate or opposition between friends can signal sociability rather than violation of modesty. The results of Sifianou's research show that the disagreement does not need to be seen only in negative terms. It does not necessarily produce conflict and immodesty, but it can be a sign of intimacy and socialization and may not be destructive but rather strengthen relationships with the other person unlike the opinion of Myers 2004: 112), who observed that disagreement had acquired a bad name, it was considered as a kind of failure between interactants. In line with Myers, Pomerantz, who considered that disputes were disliked because they disagreed with each other, made them uncomfortable, unpleasant, difficult, risking threats, insults or violations, while agreeing with each other was comfortable, supportive, strengthening, and possibly sociable, because this shows that the interlocutor thinks the same.

\section{Conclusion}

The results of the research on politeness strategies of the participants of the KBJ VI who received FTAs in responding and responding to FTAs regarding themselves were suspected, 4 people chose the speakers' positive face politeness strategy, namely M1 to P1, M2 to P2, M3 to P3, and M4 to P4. They tend to choose to be cooperative with speakers who have launched FTAs against themselves. Among them there are those who respond with jokes and laugh out loud, and choose to respond with a smile without words. Except for M5 in response to the F5 launched by P5 which consisted of 5 people, he responded with a negative face politeness strategy. In the case of $\mathrm{K} 1, \mathrm{~K} 2, \mathrm{~K} 3, \mathrm{~K} 4$, the politeness strategy chosen by M1, M2, M3, M4 is in line with the valley teachings (humble) in order to maintain the situation and conditions so that there are no fluctuations in understanding disputes. The speech partner is cooperative in 
order to please the speaker, according to the teachings, to build up the interests of others (trying to make others feel good). Case K5 shows that M5 did not just accept TFA from P5. He takes a defensive attitude in his attitude I don't want to be determined by someone else, as the demonstration did not accept just what P5 delivered in response to his presentation.

\section{Acknowledgments.}

This research will not succeed without the assistance of several parties, including Drs. Nursatwiko, as the person in charge of organizing the KBJ VI, which has allowed the author to record the entire course of the trial in the activity. I also express my gratitude to several colleagues who helped the recording process, namely Drs. Bambang Suta P., M.Hum., Bro. Benedikta, S.S., Mr. Dana Litiana, S.S., Dra. Solikhatul Mu’tiyah, Pantaria Noor Fitri, S.K.M. who have helped to record all the trials that took place in the KBJ VI. And other colleagues that I can't mention one by one. Hopefully all of their services are counted as worship, and get equal rewards from God the Almighty.

\section{References}

[1] Bavelas, J.; Gerwing, J.; Healing S., 2017. "Doing Mutual Understanding. Calibrating With Micro-sequences in Face-to-Face Dialogue" dalam Journal of Pragmatics 121 (2017) 91-112.

[2] Brown. P. and Levinson, S. C.. 1978. "Universals in Language Usage: Politeness Phenomena". In E.N. Goody.ed. Questions and Politeness. 56-289. Cambridge: Cambridge University Press.

[3] Brown. P. and Levinson, S. C. 1987. Politeness Some Universals in Language Usage. Great Britain: Redwood Burn Ltd., Trowbridge, Wiltshire.

[4] Cutting, J..2002. Pragmatics and Discourse. London: Routledge.

[5] Fraser, B. 1990. "Perspectives on Politennes". [Electronic Version]. Journal of Pragmatics 14, 219-236, $\quad$ Retrieved $\quad$ Oktober $\quad 16, \quad 2011 \quad$ From http://www.sciencedirect.com/science/article/pii/037821669090081N

[6] Geertz, Hildred. 1961. The Javanese Family. A Study of Kinship and Socialization. The Free Press og Glrncoe.

[7] Gil, J. M. 2012. "Face-Threatening Speech Acts and Face-Invading Speech Acts: An Interpretation of Peloteness Phenomena" dalam International Journal of Linguistics. Vo. 4. No. 2.

[8] Goffman, E., 1956. The Presentation of Self in Everyday Life. Univercity Of Edinburgh: Social Sciences Research Centre.

[9] Goffman, E., 1967. Interaction Ritual: Essays on Face to Face Behavior. New York: Garden City.

[10] Gu, Yueguo, 1990, "Politeness Phenomena in Modern Chinese. Journal of Pragmatics 14.2: 237-257.

[11] Guan, X. and Lee, H. E. 2017. "Fight and Flight: A Multilevel Analysis of Facework Strategies in Intercultural Face-Threatening Acts" dalam International Journal of Intercultural Relations 58 (2017) 60-81.

[12] Gunarwan, Asim, 2007. Pragmatik, Teori dan Kajian Nusantara. Jakarta. Universitas Atma Jaya.

[13] Fraser, Bruce. 1990. "Perspectives on Politeness", Journal of Pragmatics 14: 219-236.

[14] Harjawiyana, H. 2001. Marsudi Unggah-Ungguh Basa Jawa. Yogyakarta: Penerbit Kanisius.

[15] Huang, Y.. 2007. Pragmatics. Oxford: University Press.

[16] Ide, Sachico. 1989. "Formal Forms and Discemment: Neglected Aspects of Linguistic Politeness. Multilingua 8 (2), 223-248. 
[17] Kedves, A. 2013. "Face Threatening Acts and Politeness Strategies in Summer Scholl Applicatioan Calls" dalam Jeziikoslovlje. 14.2-3 (2013):431-444.

[18] Kementerian Pengadjaran Pendidikan dan Keboedajaan. 1947. Karti Basa. Djakarta: Kementerian Pengadjaran Pendidikan dan Keboedajaan.

[19] Kienpointner, M. 1997. "Varieties of Rudeness Types and Functions of Impolite Utterances" dalam Functions of Language 4:2 (1997), 251-287.

[20] Lakoff, G. 2011. Politeness Theory. Berkeley: University of California.

[21] Leech, G..1983. Principles of Pragmatics. London, New York: Longman Group Ltd.

[22] Magnis-Suseno, F., 1988, Etika Jawa: Sebuah Analisis Falsafi tentang Kebijaksaan Hidup Jawa. (cetakan ke-3), Jakarta: P.T. Gramedia.

[23] Mangkunegara IV, K.G.P.A.A., 1921, Wedhatama (Cetakan II), Solo: Boekh M. Tanoyo.

[24] Mangkunegara IV, K.G.P.A.A., 1922. "Wedhatama", dalam Serat Piwulng Warni-Warni. Surakarta: Perpustakaan Museum Rekspustaka Mangkunegaran (Koleksi No. A 115).

[25] Matsumoto, Y. 1988. Reexamination of the Universality of Face: Politeness Phenomena in Japanese. Journal of Pragmatics 12, 4: 403-426.

[26] Poerwadarminta, W.J.S. 1939 Boesastra Djawa. Batavia: J.B. Wolters Uitgevers Maatschapiij.

[27] Pomerantz, Anita. 1984. "Agreeing and Disagreeing with Assessments: Some Features of Preferred/Dispreferred Turn Shapes”. In: Alkinson M., Heritage, J. (Eds.). Structures of Social Action: Studies in Conversation Analysis. Cambridge: Cambridge University Press, pp. 57-103.

[28] Schiffrin, Deborah. 1984. "Jewish Argument as Sociability". Dalam Language in Society 13. 311-335

[29] Scollon \& Scollon. 1995. Intercultural Communication: A Discourse Approach. 2nd ed. (first ed. 1995), Blackwell Publishers.

[30] Sifianou, M., 1992. Politeness Phenomena in England and Greece: A Cross-cultural Perspective. Oxford: Clarendon Press

[31] Sifianou, M. 2012. "Disagreements, Face and Politeness" dalam Journal of Pragmatics 44 (2012) 1554-1564.

[32] Sumarlam, 1994. “Skala Pragmatik dan Derajat Kesantunan Tindak Tutur Direktif”, dalam jurnal Klitika. Sukoharjo: Univet.

[33] Suwadji. 2013. Ngoko Krama. Yogyakarta: Balai Bahasa Prov. DIY.

[34] Suyami, 2001. Serat Cariyos Dewi Sri dalam Perbandingan. Yogyakarta Penerbit Kepel Press.

[35] Thomas, J. 1995. Meaning in Interaction: An Introduction to Pragmatics. New York: Longman Group Ltd.

[36] Tim Penyusun Kamus Badan Bahasa, 2008. Kamus Bahasa Indonesia. Jakarta: Pusat Bahasa

[37] Watts, Richard J., 2003. Politeness. Cambridge University Press, Cambridge.

[38] Zajdman, A.. 1995. "Humorous face-threatening acts: Humor as strategy". In Journal of Pragmatics 23 (325-339). Israel: Elsevier 